\title{
Research on the Reform of Undergraduate Computer Courses Based on OBE Model
}

\author{
Xing Libo*1,a ${ }^{\text {Xu Yan }}{ }^{2, \mathrm{~b}}$ \\ ${ }^{1}$ Heilongjiang International University Department of Information Engineering Harbin, Heilongjiang, China \\ ${ }^{2}$ Harbin Finance University, Department of Accounting, Harbin, Heilongjiang, China
}

\begin{abstract}
Computer public course is a compulsory course for college students, which plays a very important role in students' future study and work. Therefore, practice and application must be the main body in teaching. University undergraduate computer public courses should make full use of the characteristics of the course, use the OBE model to guide the teaching output, take "facing the society, aiming at the post, strengthening ability, assisting major" as the guiding ideology, establish the teaching concept of "teachers as the leading role" and "students as the main body", so as to create high-quality teaching links of computer public courses.
\end{abstract}

\section{INTRODUCTION}

At present, results based education (OBE) has been widely valued and applied by educators in colleges and universities. It is a change of traditional education mode and a scientific, reasonable and advanced teaching concept. OBE is oriented by social needs and centered on students' learning outcomes. It develops designs and implements teaching process by paying attention to students' teaching achievements. OBE emphasizes the evaluation and assessment of students' learning achievements, focusing on what students can do after learning rather than how to learn?

In the concept of results oriented education, students' learning achievements are more reflected in practical application, which emphasizes what kind of ability students should have, how to apply the knowledge they have learned to practice and how to cultivate students' ability more effectively. Learning achievements, as the embodiment of students' mastery of the knowledge they have learned in school, is more specific and effective describe the form of student achievement. Students' knowledge and skills, knowledge literacy and knowledge levels are expressed in the form of learning outcomes. Therefore, learning outcomes can be used to describe various forms of learning.

\section{ANALYSIS ON THE NECESSITY OF THE REFORM OF UNDERGRADUATE COMPUTER COURSES}

\subsection{Training Computer Talents to Meet the Needs of the Society}

In order to adapt to the rapid development of society for talents as soon as possible, colleges and universities should reform the original teaching curriculum when carrying out teaching activities. Focus on the current stage of university computer public courses teaching application mode and teaching practice content and other aspects of multi-dimensional research and analysis. The design of computer professional courses should be in line with the characteristics of undergraduate colleges and universities, and a practical teaching mode of computer public courses with professional integration and professional pertinence should be established. Through the study of computer public courses, students can improve their computer skills and application technology, improve their autonomous learning ability, practical operation ability and innovative application ability by using various resources, enable students to have the computer application ability in professional fields and related work, and promote the development of students' personal skills. Such curriculum construction makes students keep pace with the pace of social development, which can not only lay a solid foundation for students to enter the society, but also provide excellent strength for the development of modern enterprises and cultivate applied and applicable talents for social employing units. 


\section{2 "Internet +" is an Important Opportunity for Curriculum Reform}

With the advent of the "Internet + " era, the rapid development and wide application of computer technology and network technology have brought farreaching impact on the development of China's education, and also an important opportunity for the reform of undergraduate computer public courses in our university. At present, colleges and universities have set up computer basic and professional courses, which plays an important role in promoting the cultivation of comprehensive and professional IT talents. Under the requirements of "Internet +", the computer public courses in universities should set up relevant teaching contents to keep pace with the times, and strengthen the practical teaching links more specifically. Through the application of "Internet +", the reform process of university computer public course with achievement oriented as the core has been accelerated.

\subsection{The Era of Artificial Intelligence Puts Forward Higher Requirements for Computer Public Courses}

Now is the era of rapid development of information, but also the era of artificial intelligence, undergraduate computer courses should not be weakened, but also should be strengthened, which is not only the necessary knowledge and skills of modern college students and the necessary means to adapt to social survival, but also an essential part of cultivating college students' comprehensive quality, and an important part of cultivating innovative talents. The integration of production and education, school enterprise cooperation, is an important part of the current undergraduate education, which guides the direction of the development of undergraduate computer education, creates opportunities for the reform and development of computer public courses, and puts forward higher requirements.

\section{PROBLEMS IN THE CONSTRUCTION OF UNDERGRADUATE COMPUTER COURSES}

\subsection{The Teaching Mode is out of Date and Lacks of Scientific and Technological Elements}

Due to the different enterprises, different talents are needed. At present, the traditional teaching mode is still used in the computer course teaching, which trains students in batches. The teacher is the main body and the classroom is the center. The teacher is the imparter of knowledge and the student is the receiver of knowledge. The teacher mainly teaches with PPT courseware, supplemented by computer operation. This kind of teaching mode belongs to indoctrination education. The students are in a passive receiving state. The teaching mode is old-fashioned, single and boring. Students' learning initiative is ignored. The interaction between teachers and students is insufficient. Students' enthusiasm in class is not high, and the effect of listening is not ideal. In addition, the quality of students themselves is poor, and they have no interest in the traditional classroom, which leads to a vicious circle of teaching effect, and new teaching methods are urgently needed to change the current teaching state.

\subsection{Teaching Equipment is Backward, Lack of Software and Hardware Equipments}

At present, the undergraduate computer courses are completed in the computer room, and the experimental sites for students and teachers are limited, which leads to the teachers' teaching practice cannot be realized reasonably. At the same time, with the progress of science and technology, the computer technology is developing rapidly, and the software resources of the school are not updated in time, resulting in students' learning cannot keep up with the market demand. The shortage of undergraduate teaching funds will bring some problems, such as less computer class hours, obsolete teaching equipment, untimely update of teaching software and stagnation of computer room construction and maintenance.

\subsection{The Teaching Content is out of Touch and Lacks Practical Application}

According to the needs of social development, the undergraduate computer training course is also in constant reform, but the intensity of reform is small. The content of computer training course has not been able to keep pace with the times, or some courses of office software application and equipment have been set up, which does not involve "Internet of things +", big data and other computer cutting-edge content, which is seriously out of line with the needs of enterprises, and has not played a role in cultivating students' comprehensive quality. Therefore, it is necessary to strengthen the reform of computer training course, set up the computer content needed by social enterprises, improve students' practical ability, and cultivate applied talents needed by enterprises.

\section{THE PRINCIPLE OF COMPUTER COURSE SETTING BASED ON OBE}

\subsection{Combine Unity with Flexibility}

In view of the reform of undergraduate computer courses, the university should not only abide by the unity of relevant national policies, but also form its own professional characteristics based on the characteristics of regional economy. The curriculum system should combine the change of the enterprise demand for talents, teachers adjust the content and teaching methods of the course in time, and change the schedule of the class hours according to the actual situation, so as to effectively realize the cultivation of students' professional ability, make it more suitable for the future employment market and achieve better development. 


\subsection{Adapt to the Development of Computer Industry}

In the reform of computer public curriculum, teachers should fully consider the current development of computer related industries, understand the latest technology update dynamics of the computer industry, so as to adjust the curriculum based on this, ensure that students can receive the latest technical knowledge education, make the courses set up to keep pace with the development of the industry, and effectively improve students' professional ability. With the rise of artificial intelligence and big data, as well as the teaching method of combining industry university cooperation and flipped classroom, the content reform of computer public basic courses for all college students should keep pace with the times and iterate constantly to adapt to the update speed of computer knowledge.

\subsection{Combine Production, Teaching and Learning}

In the actual undergraduate computer curriculum reform, teachers can introduce "integrated teaching", do a good job in the integration of theory and practice, implement the combination of production and learning, combine theoretical knowledge teaching with production practice, and on the basis of paying attention to the cultivation of students' professional ability, carry out professional qualification certificate system through professional vocational and technical grade assessment, and ensure the certificate quality, so as to help students better employment. The construction of computer curriculum system ensures that the curriculum structure is more scientific and reasonable, and can meet the needs of students 'knowledge acceptance. Through the course design, students 'comprehensive quality can be effectively improved, and the course contents can be reasonably selected around the three basic elements of professional attitude, professional ability and personality development to ensure the cultivation of students' computer ability.

\section{REFORM MEASURES OF COMPUTER PUBLIC COURSE BASED ON OBE}

\subsection{Results Oriented Teaching Mode, Creating Diversified Teaching}

Based on the thought of OBE and combined with modern educational means, the teaching reform of computer basic course is carried out.

- First, we should keep pace with the times, establish a network teaching platform for basic computer courses, use modern teaching modes such as micro class and flipped classroom to stimulate students' interest in learning basic computer courses, enhance students' autonomy in learning basic computer courses, and truly realize the student-centered teaching mode.

- $\quad$ Second, with the advent of media age, scientific and effective use of network resources for learning is the trend of modern higher education development, and also in line with the needs of modern university teaching reform. In the process of learning, teachers and students need to make full use of network resources and study through the network platform. Online learning is the main form of modern students' learning. Teachers and students make full use of the resources of campus network and Internet, expand the scope of practical teaching, improve the level of practical teaching, and realize network assisted teaching.

- Third, teachers upload teaching materials through the network platform. Students can study on the network without the limitation of time and space. The network platform can also communicate and complete the corresponding practical tasks. Teachers and students can communicate through the network platform, which improves the interaction and plays a guarantee role in students' learning.

\subsection{Strengthen the Construction of Training Room and Introduce More Advanced Equipments}

Undergraduate computer public course can effectively improve students' computer practice ability, realize the effective cultivation of students' professional ability, and meet the professional needs of students.

- First, teachers should not only do a good job in the reform of curriculum system and methods, but also increase investment in external hardware facilities to do well in reform and expansion. Therefore, the school should increase the investment and construction of the training room; introduce more advanced computer equipment, so that students can get better practical experience in the process of training, which has a more positive impact on the cultivation of students' professional ability.

- Second, teachers should also pay attention to optimize the proportion of theoretical teaching and practical training of computer courses, and appropriately incline the teaching to practical training, so as to give students more practical opportunities effectively improve their practical ability and help those master more professional skills.

\subsection{Promote Learning by Competition and Stimulate Students' Initiative in Autonomous Learning}

The purpose of the student competition is to further improve their practical and application ability, promote and popularize the majority of students and teachers to improve the core ability of operation, to be in line with international standards, to promote teaching reform, to create a solid foundation for computer education, and to cultivate and improve students' workplace competitiveness. In order to better stimulate students' learning enthusiasm and autonomy, international and 
domestic competitions related to information literacy are used to improve students' computer operation ability, and international and domestic computer application related certificates are used to replace the examination. In the process of competition, students have deepened the basic computer skills and information literacy knowledge, and have a better grasp of the ability to solve practical problems by using computers.

\subsection{Changing the Roles of Teachers and Students to Improve Students' Learning Efficiency}

Teachers should change the teaching method from "teaching centered" to "learning centered".

- First, in the process of teaching explanation, teachers lead out problems through projects and let students find solutions themselves. In this process, teachers are no longer simply explaining the role, but become the helper, collaborator and guide to lead students to solve problems, and let students participate in and actively practice to solve problems in learning. In this way, in the boring theory class, can stimulate students' interest in learning, and then improve learning efficiency.

- Second, maximize the students' learning potential, increase the opportunities of project practice in class and after class. Only by doing more, can students find and solve problems, so as to master the knowledge they have learned. In the whole process of practice, the teacher, as a guide, uses achievements to guide the goal, adopts multilevel teaching, coordinates all experimental contents, and leaves enough space for students to think and practice. To help students successfully complete the practice, guide students to actively and independently solve their own problems.

\section{SUMMARY}

As an important part of computer basic courses, in order to better cultivate students' practical application ability of computer, this paper studies the connotation of the concept of $\mathrm{OBE}$, the curriculum teaching reform under the concept of OBE and the practical effect of results oriented computer public courses, based on the theory of OBE combining with the demand of the society for computer talents, the course teaching content is optimized, and the students' practical ability of computer operation is significantly improved, which makes graduates more able to adapt to the needs of the times and meet the needs of the society.

\section{ACKNOWLEDGMENT}

Project source: The key project of the 13th five year plan of Education Science in Heilongjiang Province in 2020, No. GJB1320332

\section{REFERENCES}

1. Ma Xianmin, Lu Shan, sun Yazhi. Research on the reform of basic computer teaching based on results oriented [J]. Modern information technology, 2019 (15): 99-100

2. Su Haiying. Under the concept of achievement oriented_College Computer_Teaching reform and practice $[\mathrm{J}]$. Computer knowledge and technology, 2018 (12): 139-140

3. Zhi-Yi Li. Promote engineering education and teaching reform to meet the certification requirements [J]. China University Teaching, 2014(6): 9-16.

4. Y.G. Dong, J.F. Song, H.Zhu, G.L.Luo. Exploration of teaching reform of drawing courses in Chinese colleges and universities based on the advanced engineering education model[C]. 2017 2nd International conference on Humanities and social science (HSS2017), Shenzhen, China. Advances in social Sciences, educations and humanities research, 83(2017):34-38.

5. Li-li guan, Xi-qiang Sun Teaching design of vocational computer course based on OBE education concept [A].Computer Knowledge and Technology, 2018(12) 98-99 